\title{
Student Attitudes towards E-Learning: The First Year Accounting Experience
}

\author{
Lily Wong \\ Centre for Strategic Economic Studies \\ Victoria University, Melbourne, Australia
}

lily.wong@vu.edu.au

\begin{abstract}
Due to the ever-changing nature of information and communication technologies, there is a constant demand and expectation for universities to incorporate increasing levels of technology into the design and delivery of their curriculum. From an academic perspective, it is of significant interest to determine whether the increased use and availability of online teaching resources have made a positive impact on students' academic performance and whether this is reflected in improved learning outcomes. This paper reports on the preliminary findings from a survey of firstyear accounting students to gauge their attitudes towards e-learning and their perceptions of the effectiveness of online options in assisting their learning in an introductory accounting subject. The impact of the online options and the effect on learning outcomes is also examined. Analysis of the results will help identify the aspects of e-learning that are most useful in supporting student learning and the review of student feedback will provide guidance for further enhancement to the design and delivery of e-learning content in this subject.
\end{abstract}

Keywords: e-learning, student attitudes, innovation, technology, online assessment, learning outcomes

\section{Introduction}

For the purpose of this paper, the term 'e-learning' is used to describe technology enhanced learning, whereby appropriate and relevant use of technology is used to augment the learning process. This may also be referred to as 'blended learning' which is often described as 'the mix of traditional methods of teaching, such as face-to-face teaching with online teaching'. Due to its simplicity, this is perhaps the most common meaning of blended learning used in a higher education context (Bliuc, Goodyear, \& Ellis, 2007).

Due to the ever-changing nature of information and communication technologies, there is a constant demand and expectation for universities to incorporate increasing levels of technology into the design and delivery of their curriculum. This has placed academic staff in a sometimes diffi-

Material published as part of this publication, either on-line or in print, is copyrighted by the Informing Science Institute. Permission to make digital or paper copy of part or all of these works for personal or classroom use is granted without fee provided that the copies are not made or distributed for profit or commercial advantage AND that copies 1 ) bear this notice in full and 2) give the full citation on the first page. It is permissible to abstract these works so long as credit is given. To copy in all other cases or to republish or to post on a server or to redistribute to lists requires specific permission and payment of a fee. Contact Publisher@InformingScience.org to request redistribution permission. cult situation with expectations of significant change within a very short and often unrealistic time-frame. One of the challenges of teaching with technology, according to (Bates \& Poole, 2003, p. xiii), 'You cannot possibly keep up with the technology. The paradox of technology enhanced education is that technology changes very rapidly and human beings change very slowly'. 
From an academic perspective, it is of significant interest to determine whether the increased use and availability of online teaching resources have made a positive impact on students' academic performance and whether this is reflected in improved learning outcomes. As much time and effort is required to design, develop and implement suitable online materials, validation of its value to an educational context is sought.

The studies of Mladenovic (2000) and Mintz and Cherry (1993) suggest that changes in accounting education should begin with the very first subject in accounting as it not only sets the tone, but also provides the foundation for further interest in accounting studies. The students enrolled in this first-year core accounting subject are a very diverse group comprising accounting and nonaccounting students from a broad spectrum of business degrees which range from music through to marketing. It is important that the curriculum material is developed with an understanding of the differences among these students. Nelson et al. (2006) identified that students in their first year have special learning needs arising from the social and academic transition they are experiencing. From multiple starting points, all students are on a journey to becoming self-managing and self-directed learners and the first-year curriculum must help get them there. The introduction of e-learning and online resources provides a greater degree of flexibility in providing support for the diverse demands of these students. Ginns and Ellis (2007) acknowledged the increasing pressure for greater integration of new technology into the student learning experience. Wells, de Lange, and Fieger (2008) found that the use of technology in educational settings assists in the achievement of learning outcomes. Buzzetto-More (2008) and Sanders and Morrison-Shetlar (2002) report that student attitudes toward technology are influential in determining the educational benefits of online learning resources and experiences.

Ginns and Ellis (2007) identify that extensive research into quality student learning in higher education has occurred by prominent researchers in the field which include Biggs, Entwistle \& Ramsden and Prosser \& Trigwell .Outcomes from their research have helped to identify key concepts related to quality learning in higher education are shown in Figure 1.

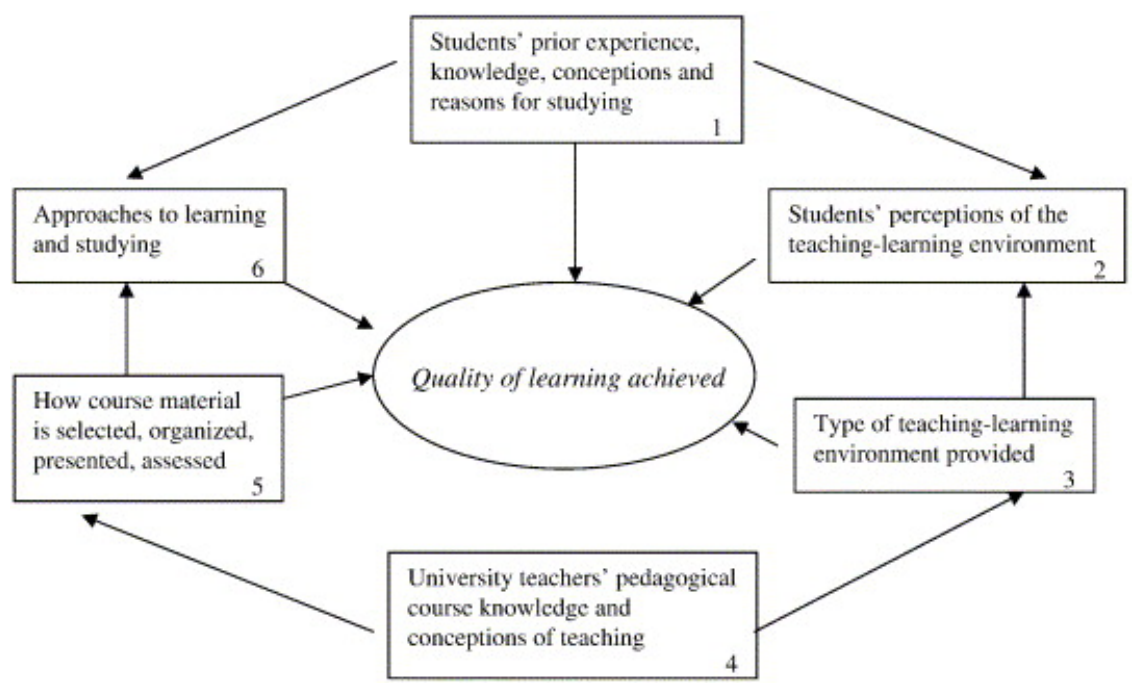

Figure 1

Concepts Related To The Quality Of Learning At University (Entwistle et al., 2002, p. 6)

Represented in Figure 1 are the key concepts arising from this research as they relate to the quality of learning achieved by students. This paper will focus on Concept 2 - student perceptions of the teaching and learning environment, to investigate whether the greater use of technology used in the teaching of this subject has enhanced their learning and whether there is any impact on im- 
proving academic performance. Apostolou et al. (2011) highlight the need for more empirical studies into the effectiveness of using technology in accounting education.

Victoria University has one of the most culturally and linguistically diverse student populations within Victoria. There are a large number of first-generation university entrants, the first in their family to attend university. Also included amongst its student population are those from a low socio-economic background and those with low university entrance scores. It is therefore important to provide additional support for their specific learning needs. One of Victoria University's key strategies is to enhance the quality of the learning experience by incorporating a greater use of technology in the teaching and learning process; this trend toward blended learning is emerging as perhaps the most prominent method of delivery in higher education (Bonk \& Graham, 2006). Since 2006 there has been an increasing amount of online resources used in Victoria University's introductory accounting subject. A review of key performance measures before and after these technological enhancements will be used to determine its impact on learning outcomes.

The introduction of WebCT, an online learning platform provided by the Blackboard Learning System, was first introduced into the introductory accounting subject in Semester 1/2006. Students were provided with a basic level of online teaching resources which included lecture notes and exam solutions. Each semester onwards additional resources were made available which now include instructional videos, recording of lectures and tutorials, as well as participation in an online tutorial. There is also greater use of the communication tools available to provide a range of methods for students to communicate with each other and their lecturers via WebCT.

\section{Methodology}

In order to measure students' attitudes towards e-learning, a mixed methodology using both quantitative and qualitative measures was adopted for this research. To gather the data required, a number of sources were utilised. This includes information retrieved from the university's student database, the Victoria University Student Information System (VUSIS), analytical tools available on the WebCT course management system and academic performance measures calculated from comprehensive records kept on student assessment. Information has also been extracted from a student survey on attitudes towards e-learning which rates the quality and usefulness of the online teaching materials to support student learning in this subject. This was conducted over three consecutive semesters commencing from Semester 1/2010 through to Semester 1/2011. Surveys were distributed at the end of each semester and student participation was voluntary.

\section{Demographic Profile}

It has been acknowledged that age, sex, socio-economic background and ethnicity contribute to and shape students' expectations of university, their adjustment to being university students, and ultimately their overall teaching and learning experience (McInnes, James, \& Mc Naught, 1995). This determined the demographic factors to be included in this study shown in Table 1. 
Table 1 - Demographic Profile of Survey Participants

\begin{tabular}{|c|c|c|c|}
\hline & $\begin{array}{l}\text { Semester } \\
1 \text { / } 2010\end{array}$ & $\begin{array}{c}\text { Semester } \\
2 \text { / } 2010\end{array}$ & $\begin{array}{c}\text { Semester } \\
1 \text { / } 2011\end{array}$ \\
\hline Number of Students Enrolled at End of Semester & 561 & 495 & 468 \\
\hline Sample Size & 172 & 112 & 143 \\
\hline Gender & $\%$ & $\%$ & $\%$ \\
\hline Male & 56 & 37 & 53 \\
\hline Female & 44 & 63 & 47 \\
\hline Mode of Study & $\%$ & $\%$ & $\%$ \\
\hline Full-Time & 88 & 88 & 87 \\
\hline Part-Time & 12 & 12 & 13 \\
\hline Which year of study are you in? & $\%$ & $\%$ & $\%$ \\
\hline 1st & 64 & 67 & 67 \\
\hline other & 36 & 33 & 33 \\
\hline Are your major studies in Accounting? & $\%$ & $\%$ & $\%$ \\
\hline Yes & 35 & 8 & 19 \\
\hline No & 65 & 92 & 81 \\
\hline Work and Study & $\%$ & $\%$ & $\%$ \\
\hline Not working & 27 & 25 & 31 \\
\hline 1-10 hours of work & 16 & 9 & 11 \\
\hline 11-20 hours of work & 30 & 44 & 31 \\
\hline 21-30 hours of work & 15 & 12 & 16 \\
\hline Greater than 30 hours & 12 & 10 & 11 \\
\hline Age & $\%$ & $\%$ & $\%$ \\
\hline Less than 20 years & 44 & 36 & 39 \\
\hline $20-29$ years & 47 & 58 & 49 \\
\hline 30 years or older & 9 & 6 & 12 \\
\hline Studied Accounting Previously & $\%$ & $\%$ & $\%$ \\
\hline Yes & 39 & 22 & 37 \\
\hline No & 61 & 78 & 63 \\
\hline Work Experience in Accounting & $\%$ & $\%$ & $\%$ \\
\hline Yes & 13 & 5 & 10 \\
\hline No & 87 & 95 & 90 \\
\hline How many lectures did you attend? & $\%$ & $\%$ & $\%$ \\
\hline None & 1 & 2 & 1 \\
\hline some & 49 & 50 & 60 \\
\hline All 24 lectures & 50 & 28 & 39 \\
\hline How many tutorials did you attend? & $\%$ & $\%$ & $\%$ \\
\hline None & 0 & 0 & 0 \\
\hline some & 41 & 52 & 48 \\
\hline All 12 tutorials & 59 & 48 & 52 \\
\hline
\end{tabular}

Table 1 provides a demographic profile of the students surveyed over the 3 semesters under review from Semester 1/2010 through to Semester 1/2011.

\section{Gender}

With the exception of Semester 2/2010 in which female students represented 63\% of the sample, the majority of students surveyed were male students. 


\section{Mode of Study}

The vast majority of students, $87 \%$ to $88 \%$ were studying in full-time mode. This figures remained consistent over the over the 3 semesters under review

\section{Year of Study / Previous Accounting Studies / Work Experience}

For a large proportion of these students, this subject is undertaken as their first semester in the first year of study at this university. In Semester 2/2010 this accounted for $67 \%$ of survey participants. A significant majority of students ranging from $61 \%$ to $78 \%$ have no previous accounting studies and the percentage of students with work experience in accounting was very low representing from $5 \%$ to $13 \%$ of this sample.

\section{Major Area of Study}

A minority of students enrolled in this compulsory accounting unit are accounting majors. In Semester $1 / 2010$, this amounted to 35\% and in Semester 2/2010 this was at its lowest with only $8 \%$ of students identified as accounting majors. This is one of the major challenges in engaging these students in the learning of accounting as it is an area of study in which there is little or no interest.

\section{Work and Study}

The proportion of students that are not working and able to fully focus on their studies ranged from $25 \%$ to $31 \%$. A significant majority of students are working and studying. Of this group of students, the percentage of students that were working between 11 to 30 hours of work each week ranged from $45 \%$ to $56 \%$. This is reflective perhaps of the generally low to medium socioeconomic status of the student demographic in which students are required to long hours to cover their educational and living expenses. More flexible learning options may be beneficial to this group to enable them to continue with their studies despite substantial work commitments.

\section{Age}

The dominant groups are those students less than 20 and those between 20 to 29 years old. These two younger groups combined represent approximately $88 \%$ to $94 \%$ of surveyed students in comparison to mature students aged 30 years or older who account for only $6 \%$ to $9 \%$ of this group.

\section{Lectures and Tutorials Attended}

There appears to be a downward trend in the percentage of students attending all lectures. This has decreased from 50\% to 39\% from Semester 1/2010 to Semester 1/2011. It is also noted that $1 \%$ to $2 \%$ of students did not attend any lectures during the semester. A similar trend is seen the percentage of students attending all tutorials. This has also decreased from 59\% to 52\% from Semester $1 / 2010$ to Semester $1 / 2011$. In contrast to lecture attendance, there were no students in this survey that did not attend any tutorials. This is probably due to students having to complete a mid-semester test. As this is a compulsory assessment for the subject, each student attended at least one tutorial.

\section{Findings}

In addition to the traditional face-to-face lectures and tutorials, in Semester 1/2010 students were introduced to some new online learning options. These included the viewing of recordings of the lectures via Lectopia as well as the opportunity to participate in online tutorials or viewing the recordings of the online tutorials via Elluminate. Access to these additional resources was through WebCT. 


\section{Students' Perceptions of Effectiveness of Learning Options}

To gauge how students perceived the effectiveness of each of these options, a 4 point rating scale was used with $1=$ not at all effective, 2 = some effect, $3=$ effective and $4=$ very effective. This scale applies to Table 2 and Table 3.

Table 2 - How effective was each of these options in assisting your learning in this subject?

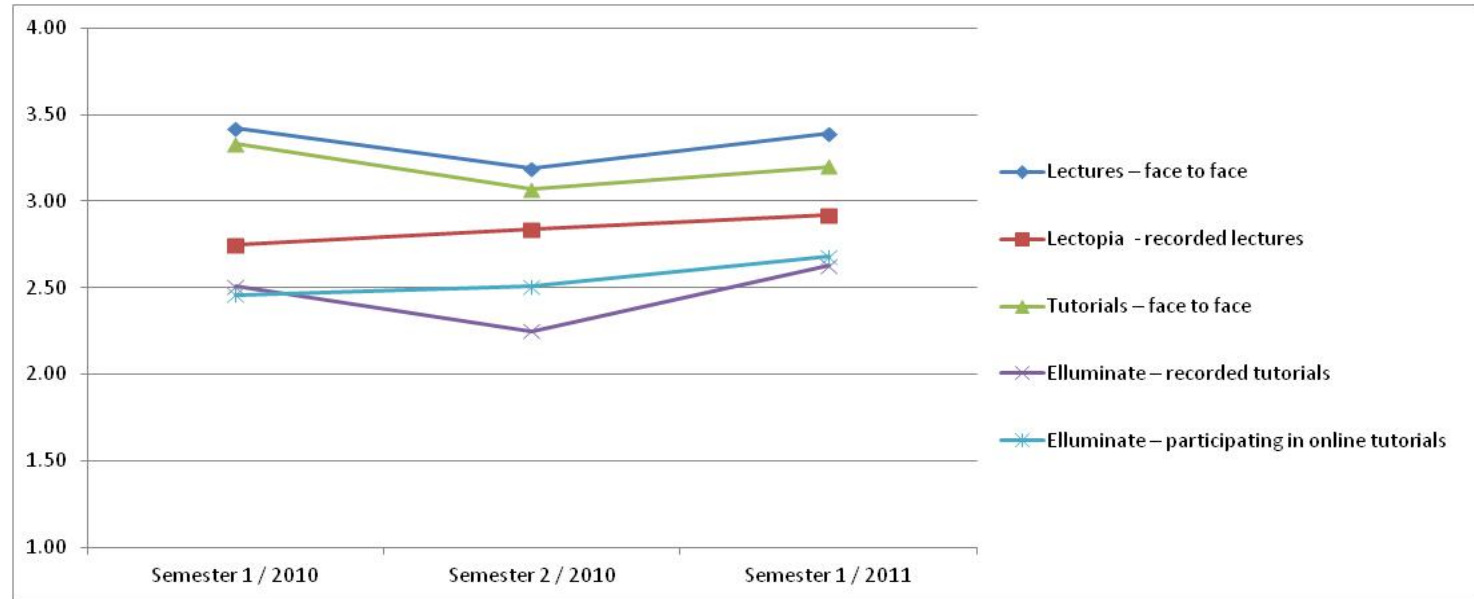

\begin{tabular}{|l|c|c|c|}
\hline & $\begin{array}{c}\text { Semester } \\
\mathbf{1 ~ / ~ 2 0 1 0}\end{array}$ & $\begin{array}{c}\text { Semester } \\
\mathbf{2 / 2 0 1 0}\end{array}$ & $\begin{array}{c}\text { Semester } \\
\mathbf{1} / \mathbf{2 0 1 1}\end{array}$ \\
\hline Lectures - face-to-face & 3.20 & 2.94 & 3.27 \\
\hline Lectopia - recorded lectures & 2.47 & 2.62 & 2.77 \\
\hline Tutorials - face-to-face & 3.14 & 2.87 & 3.12 \\
\hline Elluminate - recorded tutorials & 2.39 & 2.15 & 2.49 \\
\hline Elluminate Live - participating in online tutorials & 2.34 & 2.35 & 2.64 \\
\hline
\end{tabular}

The mean score for the effectiveness of each of these options in assisting student learning dropped in Semester 2/2010 with the exception of viewing the Lectopia recorded lectures and participating in the Elluminate Live online tutorials. Also both these options showed a gradual increase over three consecutive semesters. The overall decline in the mean scores for Semester 2/2010 may be attributed to the student profile for this period. With reference to Table 1 , it can be seen that $92 \%$ of this particular group are non-accounting majors of which $78 \%$ have no prior studies in accounting, the largest proportion in these categories across the 3 semesters surveyed. It also shows that $44 \%$ of these students were working between $11-20$ hours, which is substantially higher than the 30\% and 31\% recorded for Semester 1/2010 and Semester 1/2011 respectively. This may have contributed to the lower attendance rates for Semester 2/2010 which show that only $28 \%$ of these students attended all lectures and $48 \%$ attended all tutorials, the lowest over the 3 semesters reviewed. This may have attributed to the increase in the effectiveness of the Lectopia recorded lectures and Elluminate recorded tutorials to make up for missed classes during the semester. These factors had a minimal effect on the participation in online tutorials in assisting their learning in Semester 2/2010 but there was a considerable increase in the mean from 2.35 to 2.64 in Semester 1/2011. Student awareness may have been influenced by the greater promotion of the online tutorials during this semester to improve on the low number of enrolments for this off-campus learning option.

Despite having 3 new online options readily available via WebCT, strong support of traditional approaches to teaching was evident. Students ranked the delivery of face-to-face lectures as the most effective in assisting their learning in this subject, closely followed by face-to-face tutorials. 
These results appear to be consistent with earlier research on student attitudes toward teleteaching and traditional face-to-face contact. Preference for face-to-face teaching was also reported by Halabi et al. (2005) in a similar study.

The viewing of recorded tutorials was rated lowest as only having some effect in assisting their learning. This is perhaps indicative of their preference for active involvement through student interaction rather than passive viewing of online recordings. Bates \& Poole (2003, p. 98) state that "most theories of learning suggest that for learning to be efficient, it needs to be active ... the learner must respond in some way to the learning material." Students learn better when they are actively engaged with their learning rather than being passive receptacles of information. This may have influenced the trend in responses shown in Table 3.

\section{Students' Perceptions of Potential Effect on Assessment Outcomes}

In Table 3, the mean score for the effectiveness of each of these options in potentially affecting students' assessment outcomes showed a similar trend to Table 2, with face-to-face lectures perceived to be slightly more effective than face-to-face tutorials.

Table 3. To what extent did each of these options potentially affect your assessment outcomes?

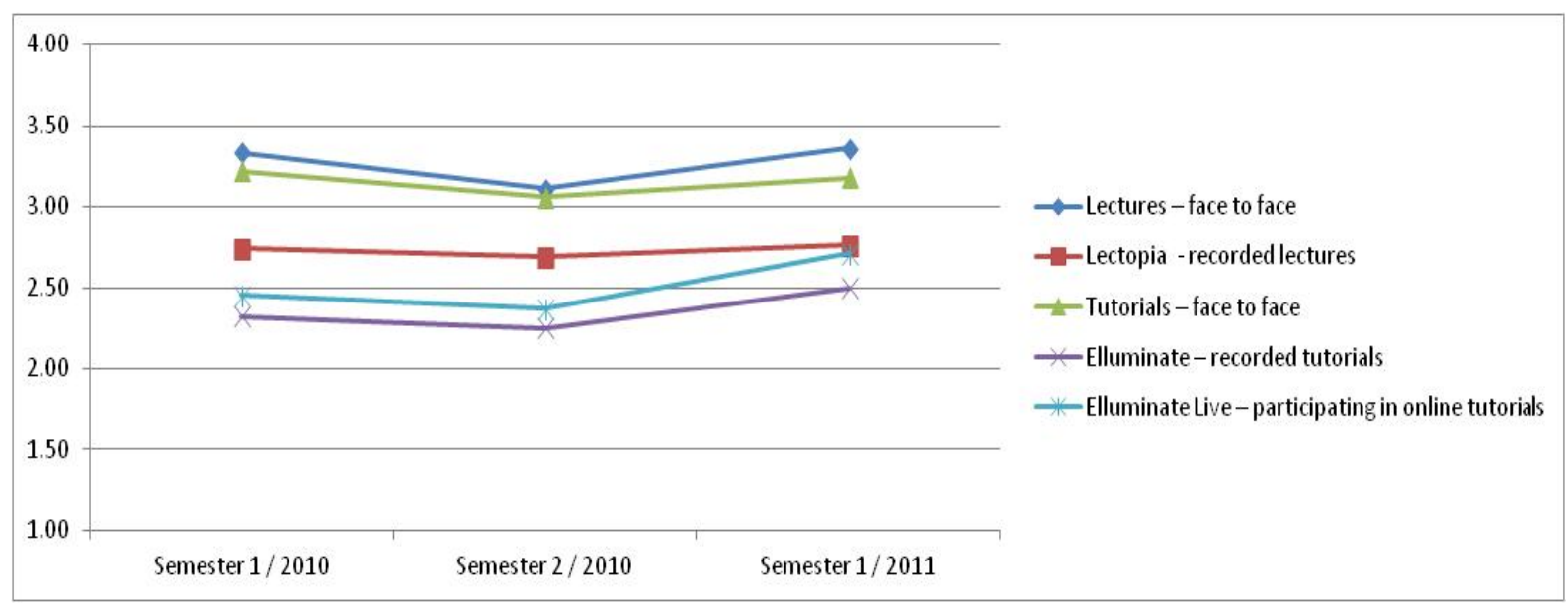

\begin{tabular}{|l|c|c|c|}
\hline & $\begin{array}{c}\text { Semester } \\
\mathbf{1 / 2 0 1 0}\end{array}$ & $\begin{array}{c}\text { Semester } \\
\mathbf{2 / 2 0 1 0}\end{array}$ & $\begin{array}{c}\text { Semester } \\
\mathbf{1 / 2 0 1 1}\end{array}$ \\
\hline Lectures - face-to-face & 3.33 & 3.11 & 3.36 \\
\hline Lectopia - recorded lectures & 2.74 & 2.69 & 2.76 \\
\hline Tutorials - face-to-face & 3.22 & 3.06 & 3.18 \\
\hline Elluminate - recorded tutorials & 2.32 & 2.25 & 2.50 \\
\hline Elluminate Live - participating in online tutorials & 2.45 & 2.37 & 2.71 \\
\hline
\end{tabular}

Of the online options, the viewing of recorded lectures rated highest and this was maintained across the 3 semesters. The overall decline in the mean scores for Semester 2/2010 may have also been influenced by the student profile for this period. As previously mentioned in the commentary for Table 2, this particular group had the highest percentage of non-accounting majors with no prior studies in accounting across the 3 semesters surveyed. 
The improvement in mean scores for the Elluminate Live online tutorial participation and Elluminate viewing of recorded tutorials was most significant between Semester 2/2010 to Semester 1/2011. This may have also been due to the greater promotion of the Elluminate options as previously mentioned in the discussion of Table 2 . Enrolments still remained low with the numbers ranging between 5 to 10 students in the online tutorial. This may be perceived to be a benefit to the participants as it provides a more personalised learning experience compared to a traditional classroom of 25 students. As an instructor, one is able to better gauge the level of understanding of each individual student through the one-to-one interaction online in which student anonymity is maintained. This seemed to encourage more open discussion amongst participants and provide a more active and collaborative learning experience, particularly for those students who feel uncomfortable asking questions in a large tutorial group.

\section{Student Feedback on Online Recordings}

Presented below is a sample of comments from students who have either participated in the online tutorials or have viewed the online recordings of lectures and tutorials. It provides an insight into how these learning options helped deepen their understanding and reinforce their learning in this subject.

'I personally have found the online element and your teaching style extremely advantageous to my learning as it had been extremely helpful to me as a travelling student'.

'Thank you for the opportunity to access both the lecture recordings and online tutorial recordings. Although I attend both my tutorial and lecture I find I am able to use the recordings for better understanding of the subject. I have found them of great assistance.'

'The recordings are clear and easy to listen to especially with the company of the lecture notes and subject guide/workbook- very beneficial!'

'I understand that we should not be relying on the recording for learning. However I have found that when I'm able to return to the lecture via the recording and also replay any part I don't fully grasp on the first occasion, I find that I get a better understanding of the subject.'

\section{Learning Outcomes}

Marriott and Lau (2008) explained the merits of phased online assessment, whereby a series of assessments were delivered throughout the course. This enables students to monitor their performance, and the timely feedback provided would be beneficial in improving their future performance. A similar approach was adopted in this subject, with the introduction of online tests to help students review and test their understanding of the content in the lectures and tutorials at regular intervals during the semester.

To determine whether the online learning options had an impact in assisting the student' learning in this subject and potentially affecting their assessment outcomes, a review was conducted to compare mid-semester test results attained prior to WebCT and after the implementation of WebCT shown in Table 4. 
Table 4 - Student Performance on Mid-Semester Test

\begin{tabular}{|c|c|c|c|c|c|c|c|c|}
\hline & \multirow{2}{*}{\begin{tabular}{|c|} 
Prior to \\
WebCT \\
2005
\end{tabular}} & \multicolumn{4}{|c|}{$\begin{array}{c}\text { With } \\
\text { WebCT }\end{array}$} & \multicolumn{3}{|c|}{$\begin{array}{l}\text { WebCT Access To Recorded } \\
\text { Lectures And Tutorials }\end{array}$} \\
\hline & & 2006 & 2007 & 2008 & 2009 & $\begin{array}{c}\text { Semester } \\
1 / 2010\end{array}$ & $\begin{array}{c}\text { Semester } \\
2 / 2010\end{array}$ & $\begin{array}{c}\text { Semester } \\
1 / 2011\end{array}$ \\
\hline $\begin{array}{l}\text { Sample } \\
\text { Size* }\end{array}$ & 1,021 & 1,152 & 1,307 & 1,163 & 1,333 & 588 & 541 & 491 \\
\hline $\begin{array}{l}\text { Average } \\
\text { score } \\
\text { out of } 10\end{array}$ & 6.1 & 5.9 & 5.5 & 5.4 & 5.8 & 5.9 & 5.4 & 5.9 \\
\hline
\end{tabular}

* Sample Size is based on number of students completing mid-semester test

The mid-semester test conducted in Week 8, is a paper-based multiple-choice test which contains both practical and theory content drawn from lectures and tutorials. It is a compulsory assessment conducted in class and accounts for $10 \%$ of the final grade. From Semester 1/2006 onwards, students were provided access to weekly online tests via WebCT. By providing regular assessment with immediate feedback, the weekly online tests were designed to help students prepare for their mid-semester test. However, the average mark attained by students for 2006 of 5.9 was lower than the 6.1 attained in 2005, prior to the introduction of WebCT. The downward trend continued through to 2008 reaching its lowest point with an average test score of 5.4. In response to student feedback in 2009, students were allowed multiple attempts at the online test and the highest mark attained was used in the calculation of their final grade in this subject. This may have contributed a marginal improvement by Semester 1/2010 where the average mark increased back to 5.9 but slipped to a low of 5.4 in following semester. This could be attributed to Semester 2 which for this subject is the semester where there is generally a larger proportion of repeat students and non-accounting majors. Reference to the demographic profile in Table 1 shows that non-accounting majors represented 92\% of the students surveyed in Semester 2/2010, the largest cohort in this category over the 3 semester period. It is acknowledged that there may be other factors influencing this result. Although the average test mark was back to 5.9 in Semester 1/2011, this is still lower than the 6.1 attained prior to the introduction of WebCT. The implementation of the online assessment and the access to the online recordings did not seem to have any influence in improving students' performance on their mid-semester test.

Table 5 - Overall Pass Rate

\begin{tabular}{|c|c|c|c|c|c|c|c|c|}
\hline & \multirow{2}{*}{\begin{tabular}{|c|} 
Prior to \\
WebCT \\
2005 \\
\end{tabular}} & \multicolumn{4}{|c|}{$\begin{array}{c}\text { With } \\
\text { WebCT }\end{array}$} & \multicolumn{3}{|c|}{$\begin{array}{l}\text { WebCT Access To Recorded } \\
\text { Lectures And Tutorials }\end{array}$} \\
\hline & & 2006 & 2007 & 2008 & 2009 & $\begin{array}{c}\text { Semester } \\
1 / 2010\end{array}$ & $\begin{array}{c}\text { Semester } \\
2 / 2010\end{array}$ & $\begin{array}{c}\text { Semester } \\
1 / 2011 \\
\end{array}$ \\
\hline $\begin{array}{l}\text { Sample } \\
\text { Size* }\end{array}$ & 992 & 1,090 & 1,357 & 1,134 & 1,289 & 561 & 495 & 468 \\
\hline Pass Rate & $73 \%$ & $68 \%$ & $77 \%$ & $71 \%$ & $70 \%$ & $80 \%$ & $76 \%$ & $82 \%$ \\
\hline
\end{tabular}

* Sample Size is based on number of students completing final exam

In Table 5, a more positive outcome was evident in the overall pass rate in this subject. The improvement was most significant from 2009 to Semester 1/2010 where the overall pass rate increased from $70 \%$ to $80 \%$ which seems to coincide with the availability of recorded lectures and tutorials via WebCT. It is also acknowledged that there may be other contributing factors influencing these results. Despite the downward trend in the attendance rate of all lectures dropping 
from Semester 1/ 2010 to Semester 1/ 2011 and a similar trend in the attendance rate of all tutorials decreasing, there is a substantial improvement in the overall pass rate which peaked at $82 \%$ in Semester $1 / 2011$. This is considerably higher than the $73 \%$ pass rate attained prior to WebCT. It is interesting to note that this was achieved when the proportion of students attending all lectures had declined from $50 \%$ to $39 \%$ and the proportion of students attending all tutorials was down from $59 \%$ to $52 \%$. These low attendance rates may be attributed to the growing number of students that are working and studying. As outlined in the demographic profile in Table 1, the percentage of students that were working between 11 and 30 hours ranged from $45 \%$ to $56 \%$ over the three semesters reviewed. It appears that these students have found the online recordings a flexible learning option enabling them to continue with their studies and managing their work commitments.

\section{Evaluation of Subject Website}

The quality of the subject website and the usefulness of its main features was measured using a 4 point rating scale with 1 = low, $2=$ medium, $3=$ high and 4 = very high, not applicable was an option if students did not use the feature or did not perceive it to be useful.

As the mean scores for each feature were similar over the 3 semesters, the scores have been averaged and presented in Table 6.

\section{Table 6. To what extent were the following website features useful in your learning in this unit?}

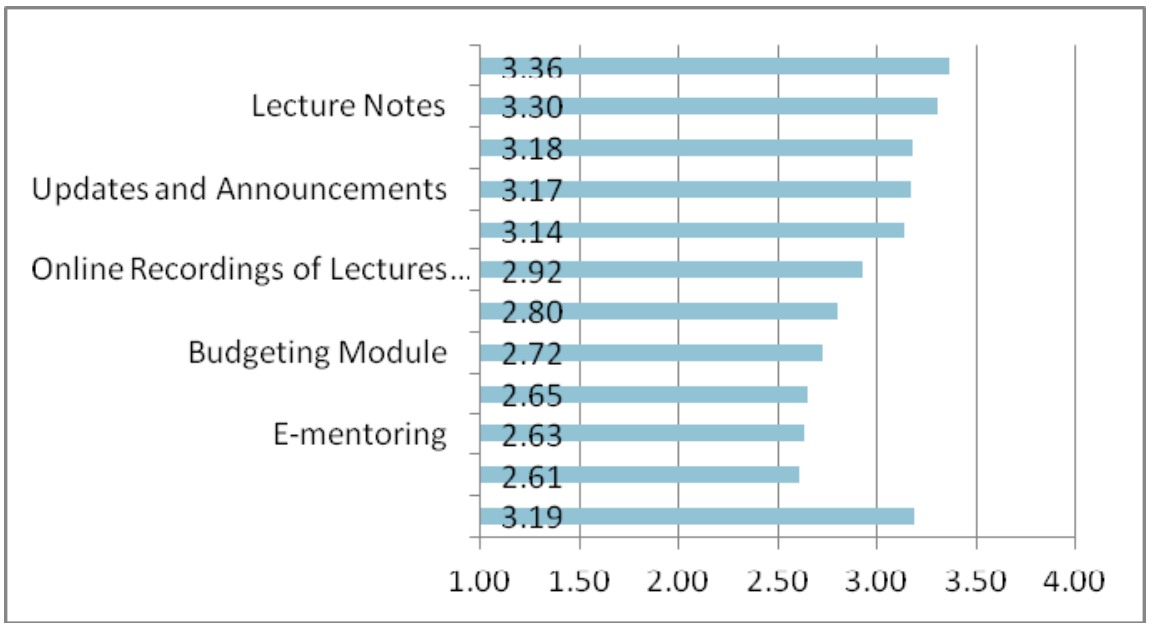

The most useful features were exam solutions (3.36) and lecture notes (3.30). This was closely followed by the weekly online tests (3.18), updates (3.17) and unit information (3.14). These results are similar to previous research on the use of WebCT and its effect on student motivation which found that various design features of WebCT, such as the provision of lecture notes, use of bulletin board, online assessment significantly influenced the level of student satisfaction (de Lange et al, 2003).

The features which enable students to communicate with each other and with teaching staff rated amongst the lowest; discussion board (2.61) and e-mentoring (2.63) but still regarded as moderately useful in their learning in this unit. This seems to be consistent with the findings from Table 2 which highlight a strong student preference for face-to-face interaction with staff and students in lectures and tutorials as the most effective in assisting their learning. Students expressed a high level of satisfaction with the overall quality of the website with a mean score of 3.19. 


\section{Suggested Improvements to Subject Website}

The survey also included an open-ended question which asked:- "What other features would you like to be included on the BAO1101 Website to help your learning?”

A review of the responses collected over the 3 semesters revealed 22 requests for skype to be used for either online consultation or additional learning support. This enables the face-to-face interaction to be maintained through the use of skype.

\section{A summary of suggested additional features include:-}

\begin{tabular}{|l|}
\hline online tutor if having difficulty understanding \\
\hline frequently asked questions \\
\hline elluminate or skype for online e-mentoring \\
\hline mobile phone help, eg, txt help for quick questions \\
\hline facebook \\
\hline discussion board to anonymously ask lecturers questions \\
\hline sub-section for new students to accounting \\
\hline a live forum would be useful if one is available in the evening \\
\hline 24 hour online help service \\
\hline twitter- works well to answer questions with minimum words \\
\hline
\end{tabular}

From the demographic profile shown in Table 1, the most prominent groups which represent approximately $90 \%$ in this survey sample are those students less than 20 years of age and those between 20-29 years of age. These suggestions may be reflective of their greater demands on the quality and range of online materials available as new technologies emerge. This appears to be a constant challenge to keep abreast with technology 'which is changing and developing faster than our capacity as individuals to adapt' (Bates \& Poole, 2003:18). These issues have also been raised in earlier studies on student motivation and its effect on levels of satisfaction (de Lange et al., 2003).

This method of collecting suggestions for additional features provides user-driven improvements from the students themselves which have the potential to make the website more appropriate for their learning needs. There were 10 responses from students highly satisfied with the quality and the extent of the website features currently used. Feedback included 'site was great', 'currently works very well' and 'happy with the way technology is used'. One comment in particular suggested that students need to take responsibility for their learning ... 'I think you have provided everything required. Students have to undertake some of the research themselves if they want to be successful’.

\section{Limitations}

It is acknowledged that there are various contributing factors other than the extent of technology used that influence the learning outcomes examined in this paper. These preliminary findings provide a starting point for further statistical analysis. 


\section{Conclusion}

The results of this research indicate that despite having 3 new online options readily available via WebCT, strong support of traditional approaches to teaching was evident. Students ranked the delivery of face-to-face lectures as the most effective in assisting their learning and potentially affecting their assessment outcomes, closely followed by face-to-face tutorials. Of the online options, the viewing of online lectures rated the highest, whilst the viewing of recorded tutorials was rated lowest. These results may be reflective of their preference for active involvement through student interaction rather than passive viewing of online recordings to better engage in the learning process.

To determine whether the online learning resources had an impact in assisting the student' learning in this subject and potentially affecting their assessment outcomes, a review was conducted to compare mid-semester test results and overall pass rates attained prior to WebCT and after the implementation of WebCT. It appears from these findings that the implementation of weekly online assessment and access to online recordings lectures and tutorials did not seem to have any impact on improving students' performance on their mid-semester test. (Greer, 2001) and (Nicol, 2006) suggest that change to assessment and innovative use of computer based assessment may positively impact on learning. However, the findings in this introductory accounting subject may have been compromised by the large proportion of these students being non-accounting majors with a low level of interest in the subject and no previous exposure to accounting.

A more positive outcome was evident in the overall pass rate in this subject. The improvement was most significant from 2009 to Semester 1/2010 where the overall pass rate increased from $70 \%$ to $80 \%$. This coincided with allowing students multiple attempts on their online test as well as the availability of online recordings lectures and tutorials. In Semester 1/2011, the overall pass rate peaked at $82 \%$ the highest attained in this first-year introductory accounting subject. With $81 \%$ of these students as non-accounting majors, this is a considerable achievement despite falling attendance rates in lectures and $42 \%$ of these students combining their studies with up to 20 hours of work per week.

\section{References}

Apostolou, B., Hassell, J. M., Rebele, J., \& Watson, S. F. (2011). Accounting education literature review (2006-2009). Journal of Accounting Education. doi:10.1016/j.jaccedu.2011.2011.08.001

Bates, A. W., \& Poole, G., (2003). Effective teaching with technology in higher education. Foundations for success., San Francisco, USA Jossey-Bass.

Bliuc, A., Goodyear, P., \& Ellis, R. A. (2007). Research focus and methodological choices in studies into students' experiences of blended learning in higher education. The Internet and Higher Education, 10(4), 231-244.

Bonk, C. J., \& Graham, C. R. (2006). The handbook of blended learning - Global perspectives, local designs. San Francisco, CA, USA: Pfeiffer - An Imprint of Wiley.

Buzzetto-More, N. A. (2008). Student perceptions of various e-learning components. Interdisciplinary Journal of E-Learning and Learning Objects, 4 113-137. Retrieved from http://www.ijello.org/Volume4/IJELLOv4p113-135Buzzetto413.pdf

de Lange, P., Suwardy, T., \& Mavondo, F. (2003). Integrating a virtual learning environment into an introductory accounting course: Determinants of student motivation. Accounting Education, 12(1), 1-14.

Entwistle, N., McCune, V., \& Hounsell, J. (2002). Approaches to study and perceptions of university teaching-learning environments: Concepts, measures and preliminary findings. Available on-line at www.ed.ac.uk/etl/docs/ETLreport1.pdf 
Halabi, A. K., Tuovinen, J. E., \& Farley, A. A. (2005). Empirical evidence on the relative efficiency of worked examples versus problem-solving exercises in accounting principles instruction. Issues in Accounting Education, 20(1), 21-32.

Garrison, D. R., \& Vaughan, N. D. (2008). Blended learning in higher education - Framework, principles and guidelines. San Francisco, CA: Jossey-Bass - A Wiley Imprint.

Greer, L. (2001). Does the method of assessment of a module improve the performance of a student? Assessment and Evaluation in Higher Education, 26(2), 127-138.

Marriott, P., \& Lau, A. (2008). The use of on-line summative assessment in an undergraduate financial accounting course. Journal of Accounting Education, 26(2), 73-90.

Mc Innis, C., James, R., \& Mc Naught, C. (1995). First year on campus - Diversity in the initial experience of Australian undergraduates. Centre for the Study of Higher Education, University of Melbourne, Australia.

Mintz, S., \& Cherry, A. A. (1993). The introductory accounting courses: Educating majors and nonmajors, Journal of Education for Business, 68(5), 276-280.

Mladenovic, R. (2000). An investigation into ways of challenging introductory accounting student's negative perceptions of accounting. Accounting Education, 9(2), 135-155.

Nelson, K., Kift, S., Humphreys, J., \& Harper, W. (2006). A blueprint for enhanced transition: Taking an holistic approach to managing student transition into a large university. Proceedings First Year in Higher Education Conference, Gold Coast, Australia.

Nicol, D. (2006). Increasing success in first year courses: Assessment re-design, self-regulation, and learning technologies. Proceedings of the 23rd Annual ASCILITE Conference: Who's learning? Whose technology? Sydney, Australia, 3-6 December, 2006, 589-598.

Sanders, D., \& Morrison-Shetlar, A. (2002). Student attitudes toward web-enhanced instruction in an introductory biology course. Journal of Research on Computing in Education, 33(3), 251-262.

Wells, P., de Lange, P., \& Fieger, P. (2008). Integrating a virtual learning environment into a second-year accounting course: Determinants of overall student perception. Accounting \& Finance, 48(3), 503-518.

\section{Biography}

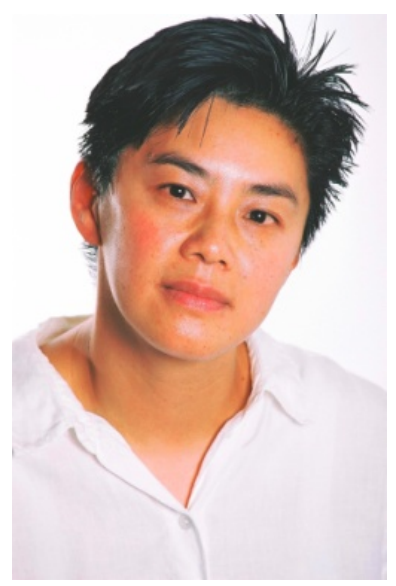

Lily Wong is the Unit Coordinator for Introductory Accounting, one of the largest student cohorts at Victoria University. Since undertaking her $\mathrm{PhD}$, she has been actively involved in the research, development and integration of online teaching resources to improve the student learning experience for first year accounting students. Lily's contribution to teaching and learning has been formally recognised as a recipient of university and national awards. These include the Australian Awards for University Teaching in which she was a finalist; an Australian Learning and Teaching Council Citation for Outstanding Contribution to Student Learning; and recipient of the Vice-Chancellor's Peak Award for Excellence in Teaching and Learning. 